Thorax (1950), 5, 105.

\title{
CYSTIC HYGROMA OF THE MEDIASTINUM \\ BY
}

\author{
H. R. S. HARLEY AND C. E. DREW \\ From the Brompton Hospital, London
}

The rarity with which cystic hygroma occurs in, and is confined to, the mediastinum justifies the report of a further case. Gross and Hurwitt (1948), after a careful review of the literature, were able to find only seven cases which they regarded as undoubted cystic hygromata, and they added a further one of their own. The author has excluded one of the cases collected by these authors, namely that reported by Eliaschewitsch (1929), in which a unilocular pedunculated cyst was found inside the pericardial cavity at post-mortem examination performed on a patient who had suffered from chronic endocarditis and fibrinous pericarditis. The case reported here thus brings the total to eight.

Blades (1946) found no case of cystic hygroma amongst the 109 patients with mediastinal tumours collected from various Army chest centres, while Watson and Diamond (1947) found only one in Navy personnel.

Cervico-mediastinal hygromata, though rare, are more common than are those confined to the chest. Gross and Hurwitt (1948) collected 19 such cases from the literature, and added two of their own to make a total of 21.

\section{CASE REPORT}

A boy aged 2 years and 2 months was admitted to the Brompton Hospital under Dr. F. Lee Lander and Mr. C. Price Thomas on September 26, 1949. Radiological examination had been performed because a small lump had been noticed on the chest wall, and a shadow was discovered in the mediastinum. As the parents were shortly to go abroad it was considered desirable to admit the child for treatment, although he had been well throughout.

The child was healthy and apyrexial. A fairly soft, but apparently solid, loculated swelling, about 1 in. in diameter, was felt in the second right intercostal space just lateral to the sternum. This was not attached to skin, and felt like a lipoma. There were no abnormal physical signs in the heart, chest, or abdomen.

Radiological Examination.-The postero-anterior views (Figs. 1 and 2) showed a convex opacity projecting to the right of the heart, and in addition there appeared to be a triangular opacity above the right diaphragm which simulated a collapse of the lower lobe. This subsequently proved to be due to a portion of the hygroma hanging almost loose in the pleural cavity. The lateral film (Fig. 3) showed that the opacity lay in the anterior mediastinum, and overlapped that due to the heart. The posterior margin of the opacity was well defined, though somewhat irregular, but its anterior margin could not be seen.

Treatment.-Right thoracotomy was performed through the fifth intercostal space on October 4, 1949, by Mr. C. Price Thomas, under general anaesthesia administered by Dr. R. Mansfield. The lung was free and normal. A lax, slate-grey coloured, cystic swelling was present in the anterior mediastinum, and was firmly adherent to 


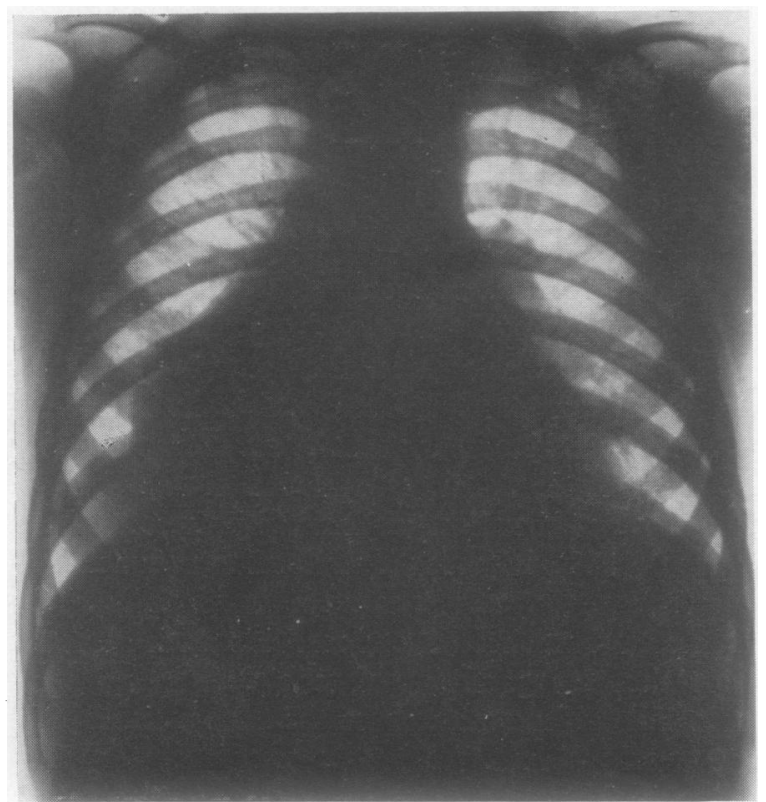

FIG. 1.-Postero-anterior film showing opacity to right of the heart.

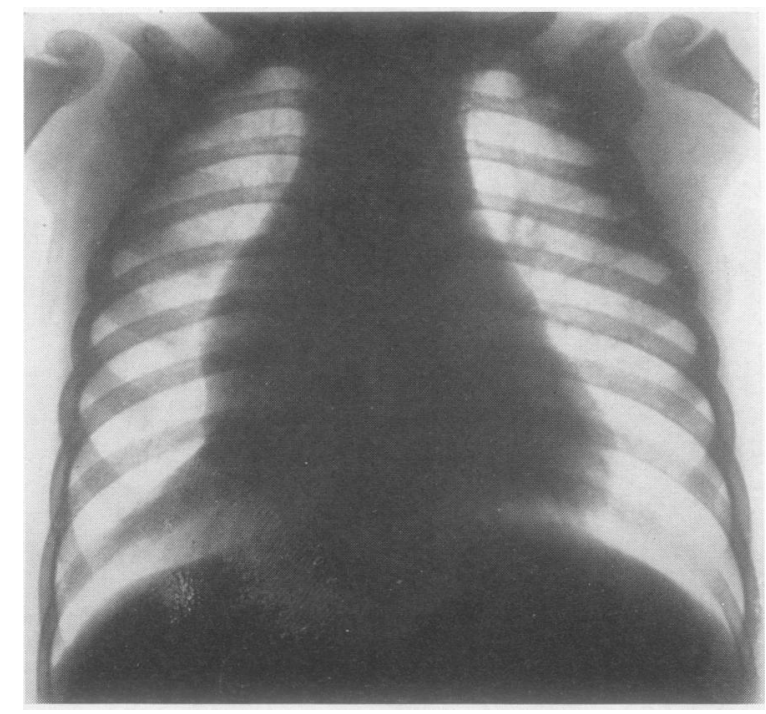

FIG. 2.-Postero-anterior film showing convex opacity to right of the heart, and an appearance simulating collapse of the right lower lobe. the front of the pericardium, the diaphragm, the back of the sternum, and to the back of the anterior ends of the second, third, and fourth intercostal spaces. The wall of the cystic swelling was thin, and its contents could be seen swirling within. By patient dissection the cyst was separated from the structures to which it was adherent, and was found to extend between the pericardium and sternum at least as far as the mid line. A small puncture was made during this dissection, but was easily closed with a pair of artery forceps. At a later date fluid was aspirated to facilitate dissection, and it was apparent that the condition was multicystic, two main loculi being present. The upper of these contained watery, strawcoloured fluid tinged with blood, and the lower a thicker and more brownish fluid which frothed on being shaken, producing a pale yellow head. The cystic mass was eventually completely removed after a very tedious dissection. No obvious macroscopic extension could be found passing through the second intercostal space to the external swelling, though a communication was assumed to exist. The mediastinal mass appeared to be more adherent in the region of the third intercostal space than in that of the second. The chest was closed without drainage.

Pathological Report.-The fixed specimen was an irregular flattened, ovoid, cystic body, $7.7 \mathrm{~cm}$. long, grey in colour. and with a smooth surface. The main body was composed of two closely adherent cysts with one common intervening 
wall, one cyst being 4.0 $\mathrm{cm}$. wide and $2.2 \mathrm{~cm}$. thick, the other being $2.0 \mathrm{~cm}$. wide and $1.8 \mathrm{~cm}$. thick. Attached to one pole of the cystic body was a solid, flattened, ovoid mass of similar external appearance which was $3.4 \mathrm{~cm}$. long, $1.7 \mathrm{~cm}$. thick, and $1.2 \mathrm{~cm}$. wide.

On section, the large cystic mass had a wall 0.1 $\mathrm{cm}$. thick with a smooth, shiny, trabeculated internal surface. On section, the solid mass showed a smooth, grey striated surface surrounding numerous cystic spaces varying from $0.6 \mathrm{~cm}$. diameter to pinpoint size, filled with faintly opalescent, colourless jelly.

The wall of the large cyst (Fig. 4) was composed of loose fatty, collagenous tissue containing many well-formed blood vessels. The cyst wall was lined internally by endothelium, but muscle fibres were not seen in the sections examined.

The solid mass (Figs. 5 and 6) was composed of fibro-fatty tissue traversed by numerous tortuous vessels of irregular shape and size. Some of these vessels appeared empty, but others contained a finely fibrillar, moderately eosinophilic material. In some places this eosinophilic material contained a few lymphocytes with a few monocytes, and sometimes with many eosinophilic leucocytes. Erythrocytes were not seen within these vessels. The walls of the vessels varied in thickness from $0.1 \mathrm{~cm}$. to approximately $0.01 \mathrm{~cm}$. , and were

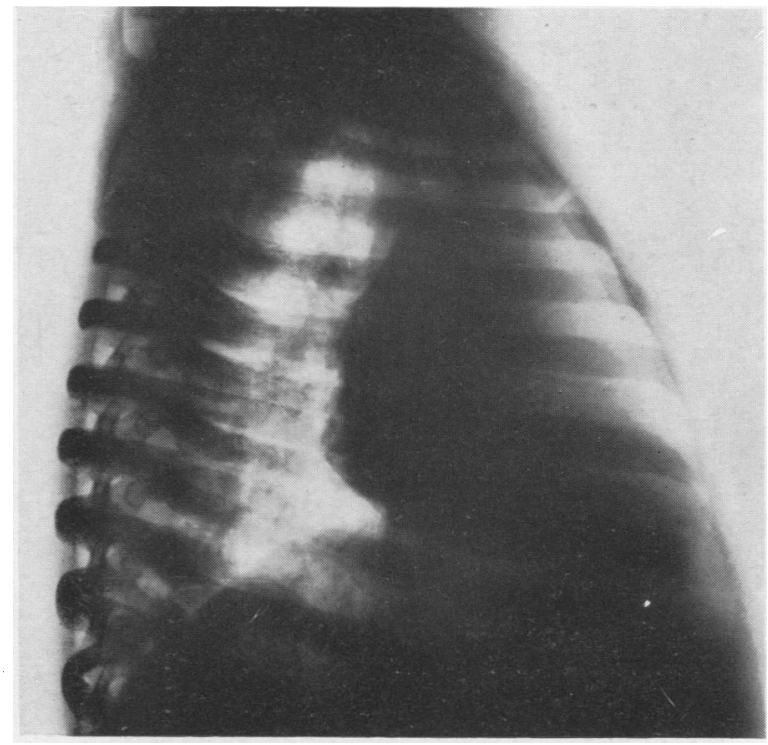

FIG. 3.-Right lateral film showing an anterior mediastinal shadow with well-defined, irregular posterior margin, but ill-defined anterior margin.

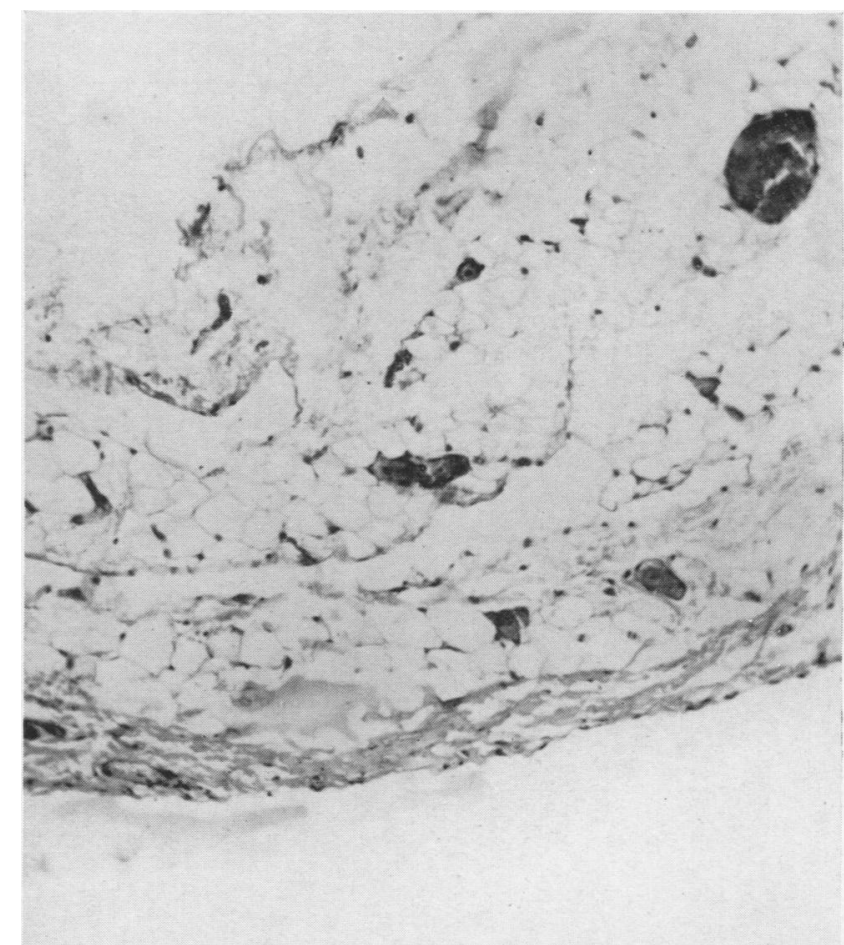

Fig. 4.-Microphotograph showing part of the wall of one of the large cystic spaces. The lower edge is the internal surface of the wall. $\times 460$. 


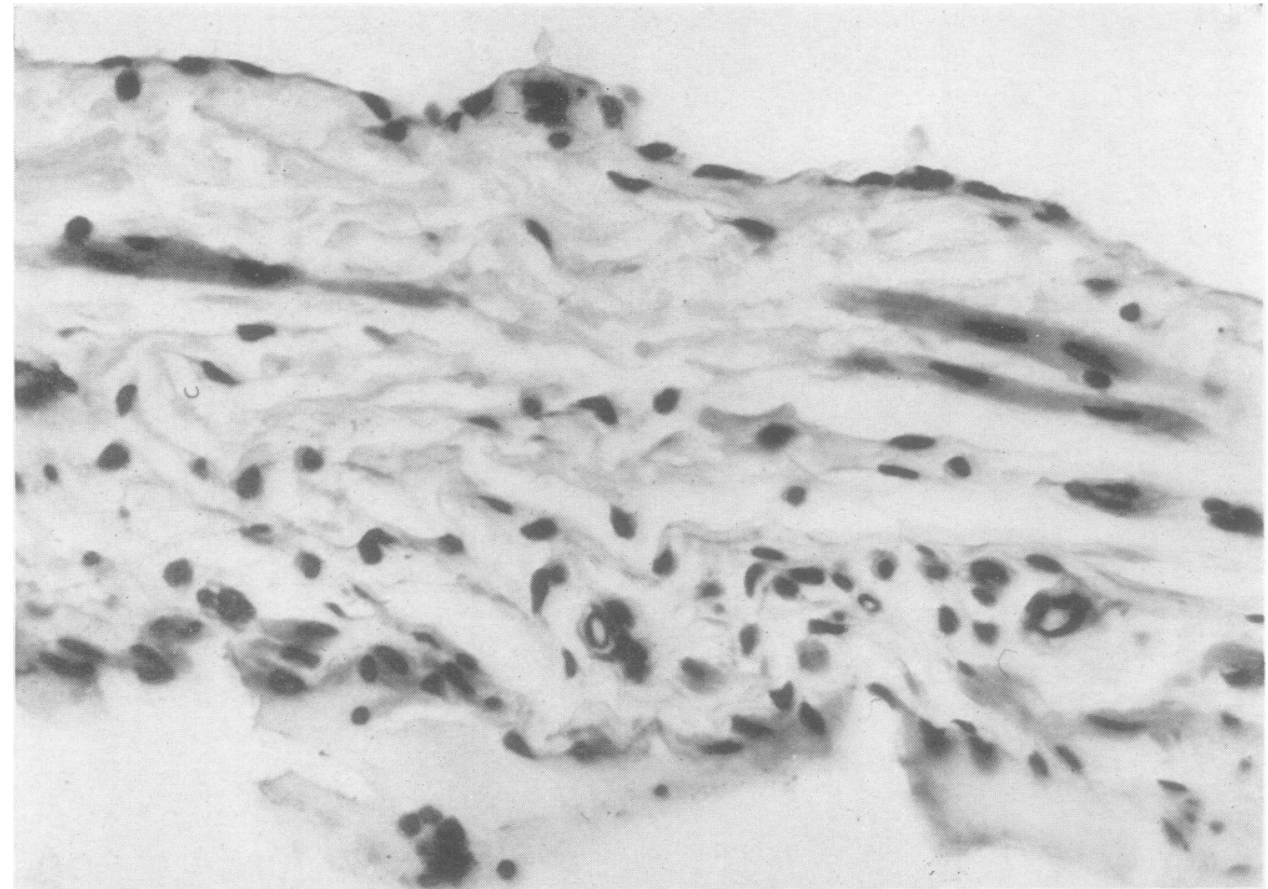

FIG. 5.-Microphotograph of part of a septum between two of the spaces in the solid portion of the hygroma showing the flattened endothelial lining cells and some striated muscle fibres. $\times 140$.

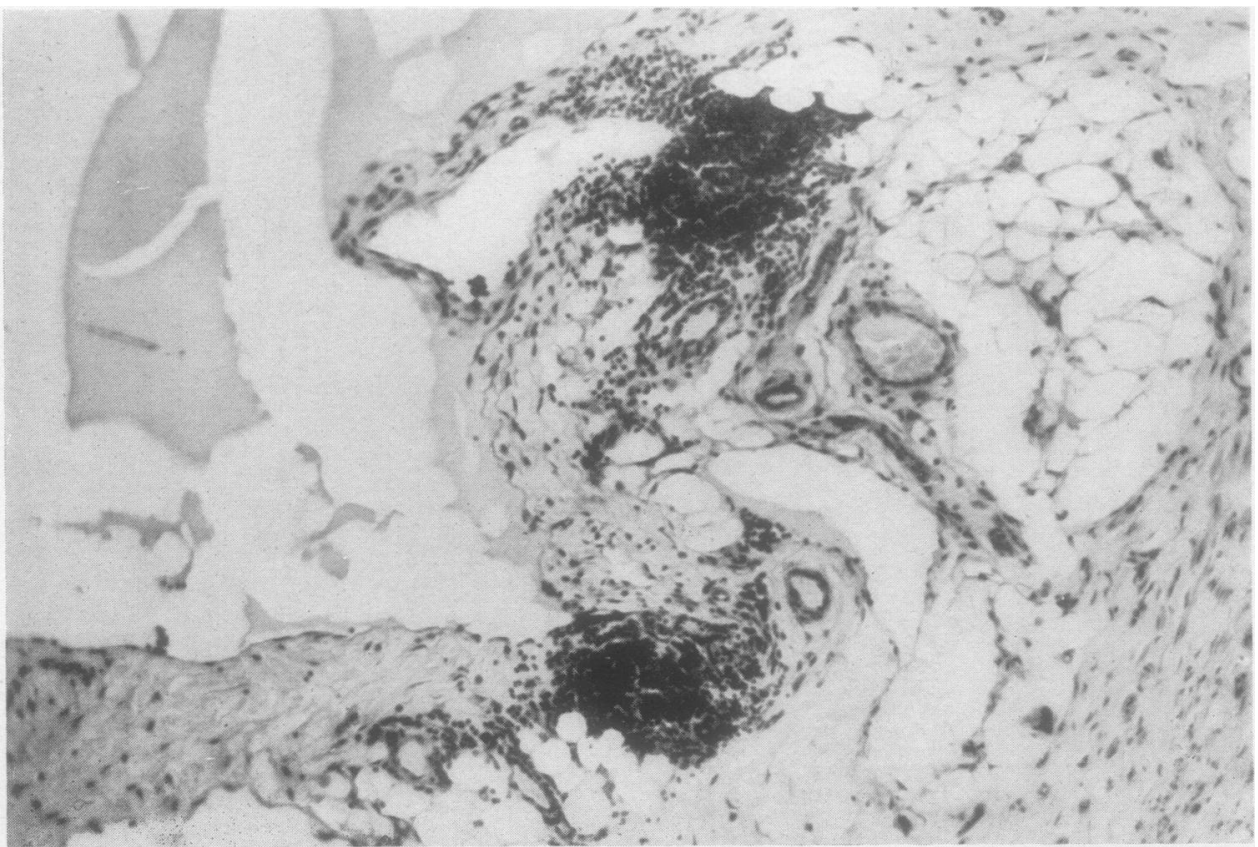

Fig. 6.-Microphotograph of part of the solid portion of the hygroma showing the fibro fatty stroma, and two lymphocytic aggregates. $\times 140$. 
lined internally with endothelium. In some places the collagenous stroma of these walls contained well-formed blood vessels, and in other places there were lymphoid aggregates and some scattered fat cells, while some had a few obliquely and longitudinally arranged smooth muscle bundles.

Progress.-The child made an uneventful recovery from the operation and was discharged home on October 15, 1949, well and apyrexial, with the right lung fully expanded. Fig. 7 shows the radiological condition of the chest two days before his discharge. The swelling in the second right intercostal space was unchanged. This was presumably similar in nature to the mass in the chest, but this was never proved.

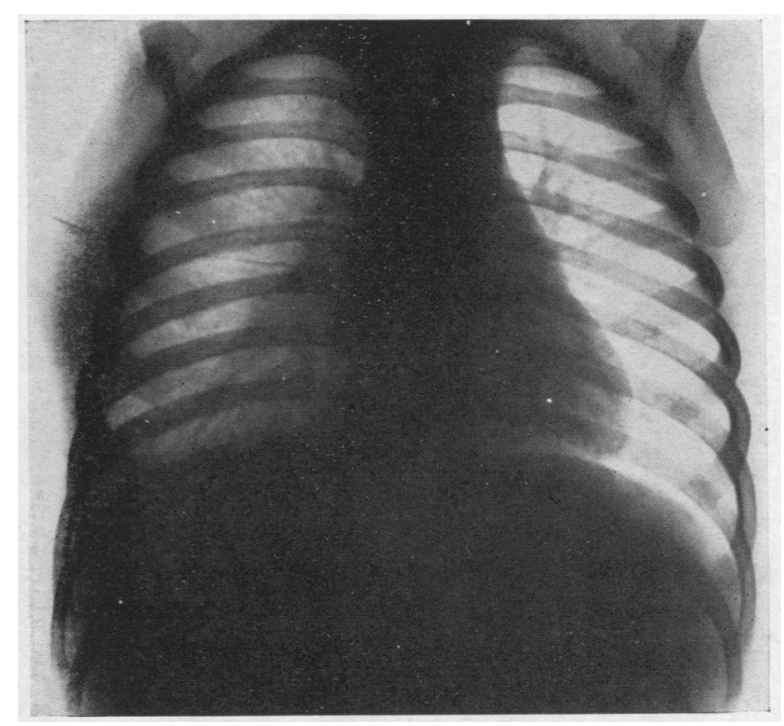

FIG. 7.-Postero-anterior film of the chest taken two days before the patient's discharge from hospital showing right lung expanded.

\section{Discussion}

Cystic hygromata are multicystic structures the spaces of which are lined by flattened endothelial cells. The various spaces may communicate with one another or be separate, the degree of communication being dependent upon the amount of pressure atrophy which occurs in the septa which originally separate the loculi. Characteristically a hygroma is adherent to neighbouring structures, and has an irregular and somewhat ill-defined outline. Aggregates of lymphoid cells, and definite lymphoid follicles with germinal centres, are not uncommonly present, while structures such as muscle bundles, blood vessels, and nerve fibres may apparently traverse the substance of the cystic mass.

Most of the features described above are explained by the histological researches of Goetsch (1938) whose paper should be consulted by all who are interested in this condition. He has shown that the lining cells of the cystic spaces give off endothelial sprouts which insinuate themselves into tissue planes and spaces. Canalization of these sprouts then takes place with the formation of new cysts which, by their growth, come to surround structures such as muscle bundles, blood vessels, and nerve fibres, so that the latter may then appear to traverse the substance of the hygroma. This mode of growth and propagation of a cystic hygroma is analogous to the processes which occur during the development of normal lymphatic tissues. Goetsch (1938) has further suggested that the endothelial cells of a hygroma have the power of creating lymphoid tissue, and that this tissue when seen in a hygroma may not represent an infiltration. Areas of lymphoid tissue or of fibrosis may result in the production of solid masses interspersed amongst the lax cystic portions of a hygroma, and such an area was present in the case reported here. 
In uncomplicated specimens the cystic spaces of a hygroma contain a thin, watery fluid, which may be clear or amber-coloured, has a very low protein content, and harbours a few cells, chiefly lymphocytes and large mononuclears. If haemorrhage or infection occurs the fluid may be frankly bloody or turbid. In some instances the cysts are filled with a translucent, gelatinous material.

Cystic hygromata, which are multicystic, ill-defined, and adherent, must be distinguished from the well-defined, thin-walled, unilocular cysts containing clear fluid which occur in the pericardiophrenic angle anteriorly. These were designated spring water cysts by Greenfield, Steinberg, and Touroff (1943), and pericardiophrenic angle cysts by Kinsella (1945). Lambert (1940) postulated that these cysts are mesothelial in origin, and that they arise from a persistent pericardial lacuna which fails to fuse with its fellows and so produces a cyst lined by flattened mesothelial cells. These may occasionally thicken up to form cells of cuboidal type. Lambert (1940) called these formations pericardial coelomic cysts, and his theory of origin is supported by Leahy and Culver (1947). Thompson (1947) and Bradford, Mahon, and Grow (1947), amongst other authors, employ Lambert's terminology.

Whatever view is held regarding the origin of the thin-walled, well-defined, unilocular, spring water cysts just discussed, whether it be from pericardial coelomic mesothelium, or from lymphatic endothelium, it seems clear that they are quite different clinically from cystic hygromata, and the two conditions should not be confused with each other. Some conditions which have been reported as mediastinal cystic hygromata were probably examples of pericardial coelomic cysts. Gross and Hurwitt (1948) endeavoured to exclude the latter from the cases of cystic hygroma which they collected.

The most probable theory of origin of cystic hygromata of the neck is that they arise from portions of the jugular lymph sacs which become separated and fail to establish subsequent communications with the venous system. It seems likely that those hygromata occurring in the mediastinum have been drawn downwards from the neck by the descent of such structures as the pericardium and diaphragm during foetal life. The possibility of downward growth from the neck is suggested by Eigler (1926) and by Michaelis (1934).

Clinical Features.-The more important clinical and pathological features of the eight reported cases are summarized in Table $\mathbf{I}$.

Age.-The age of the patients varied between two and 80 years, and only three of them were under 20 years of age. This age incidence is in striking contrast with that of cervical and cervico-mediastinal hygromata, which are nearly always found in infancy and early childhood. Gross and Goeringer (1939) reported 27 cases of hygromata in the neck. They state that $55 \%$ of these were noted at birth, $75 \%$ were discovered within the first year of life, and $90 \%$ were present by the end of the second year. The later age incidence of the mediastinal cases is almost certainly due to the fact that hygromata in this situation are clinically silent, and are often first discovered on routine radiological examination or at necropsy.

Sex.-The sex is known in seven of the eight reported cases, and six of them were males. This predominance in the male is not evident in cervical and cervico- 
mediastinal hygromata. Goetsch (1938) reported 12 cases of which seven were females. Of the 27 cervical hygromata reported by Gross and Goeringer (1939) 16 were males and 11 females. Gross and Hurwitt collected 21 cases of cervico-mediastinal hygromata in 15 of which the sex is stated. Eight of these were females. No explanation for the male sex dominance of the reported mediastinal cases is offered. It may be fortuitous, and due to the small number of cases.

Symptoms and Signs.-Symptoms are characteristically absent and were noted in only one of the eight cases, that of Skinner and Hobbs (1936). Their patient was a boy of 7 years who complained of dyspnoea, orthopnoea, non-productive cough, tightness of the chest, slow eating, and fatigue. The right side of the chest was enlarged, and the veins in the distribution of the superior vena cava were engorged. The hygroma was a large one, and was adherent to the diaphragm, pericardium, and superior vena cava. The child reported here was investigated because of the swelling in the second right intercostal space. This was presumably lymphangiomatous in nature and continuous with the mass in the mediastinum, though no macroscopic continuity could be demonstrated at thoracotomy. No other case with an external swelling has been discovered by the author. In no case did infection of the hygroma occur.

Pressure symptoms, and recurrent attacks of inflammation, especially the latter, appear to be more commonly manifested by cervical and cervico-mediastinal hygromata, than by those confined to the mediastinum. The inflammatory episodes which are prone to affect hygromata lying in the neck usually follow upper respiratory infections, such as acute tonsillitis, and this no doubt accounts for the discrepancy in this respect.

The absence of symptoms associated with mediastinal hygromata is reflected by the fact that two of the eight cases were first recognized at necropsy, while the cases reported by Watson and Diamond (1947), Gross and Hurwitt (1948) and the author were discovered unexpectedly during radiological examination of the chest.

Site.-The site of the hygroma was variable. The side was stated in four cases in all of which the right side was the one affected. In six cases the hygroma was placed anteriorly, and in one posteriorly. In Bumin's (1939) case this point could not be ascertained. The hygroma was located in the superior mediastinum in Cases 5 and 6 of Table $I$ and probably also in Case 1. The inferior mediastinum was the site of the cystic formation in Cases $3,4,7$, and 8 , and probably also in Case 2, in which it was attached to the epicardium. It thus seems probable that the hygroma affected the inferior mediastinum in five of the patients, and the superior mediastinum in three. The only posteriorly placed tumour was in the superior mediastinum. This analysis may be summarized by saying that cystic hygromata may occupy the inferior or the superior mediastinum, and that they are usually placed anteriorly and project towards the right side.

Radiological Features.-Cystic hygromata throw well-defined, homogeneous shadows on radiographs which may be rounded, ovoid, lobulated, or somewhat irregular in outline. The opacity may be of considerable size, as in Cases 3, 5, 7, 
Summary OF CASEs of Cys

\begin{tabular}{|c|c|c|c|c|c|c|c|c|c|}
\hline No. & Author & Date & $\begin{array}{c}\text { Age } \\
\text { (Years) }\end{array}$ & Sex & Site & Attachments & $\begin{array}{l}\text { Symptoms } \\
\text { Referable to } \\
\text { Hygroma }\end{array}$ & $\begin{array}{l}\text { Infec- } \\
\text { tion }\end{array}$ & Radiologica $\frac{\vec{D}_{\mathrm{B}}}{\mathrm{O}} \mathrm{i}$ \\
\hline 1 & Seidel & 1904 & 2 & ? & Thymus & Thymus & None & No & No radiogrạ \\
\hline 2 & Lenkeit & 1929 & 80 & $\mathrm{~F}$ & $\begin{array}{l}\text { Anterior surface } \\
\text { of epicardium } \\
\text { near A-V sul- } \\
\text { cus }\end{array}$ & Epicardium & None & No & No radiogra \\
\hline 3 & $\begin{array}{c}\text { Skinner and } \\
\text { Hobbs }\end{array}$ & 1936 & 7 & M & $\begin{array}{l}\text { Right inferior } \\
\text { mediastinum } \\
\text { anteriorly }\end{array}$ & $\begin{array}{l}\text { I.V.C., thy- } \\
\text { mus, peri- } \\
\text { cardium, } \\
\text { diaphragm }\end{array}$ & $\begin{array}{l}\text { Dyspnoea. Orthopnoea. } \\
\text { Non-productive cough, } \\
\text { tightness of chest, } \\
\text { slow eating, fatigue, } \\
\text { enlargement of right } \\
\text { side of chest, obstruc- } \\
\text { tion of S.V.C. }\end{array}$ & No & $\begin{array}{l}\text { Large, welB̈let } \\
\text { homogenegus } \\
\text { opacity ocour } \\
\text { lower half-os } \\
\text { side of chest } \\
\text { teriorly }\end{array}$ \\
\hline 4 & Bumin & 1939 & 25 & M & $?$ & $\begin{array}{c}\text { Diaphragm, } \\
\text { pericardium }\end{array}$ & ? & ? & $?$ \\
\hline 5 & $\begin{array}{l}\text { Sanes and } \\
\text { others }\end{array}$ & 1945 & 53 & M & $\begin{array}{l}\text { Right superior } \\
\text { mediastinum } \\
\text { posteriorly, } \\
\text { between tra- } \\
\text { chea and oeso- } \\
\text { phagus }\end{array}$ & $\begin{array}{l}\text { Trachea, oeso- } \\
\text { phagus }\end{array}$ & Non-productive cough & No & 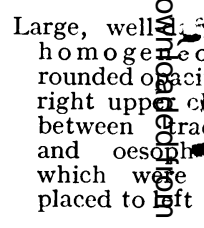 \\
\hline 6 & $\begin{array}{l}\text { Watson and } \\
\text { Diamond }\end{array}$ & 1947 & 24 & $\mathrm{M}$ & $\begin{array}{l}\text { Superior medias- } \\
\text { tinum anteri- } \\
\text { orly ? side }\end{array}$ & $\begin{array}{l}\text { Trachea, } \\
\text { S.V.C. }\end{array}$ & ? & ? & 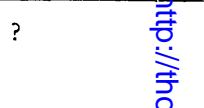 \\
\hline 7 & $\begin{array}{c}\text { Gross and } \\
\text { Hurwitt }\end{array}$ & 1948 & 32 & $M$ & $\begin{array}{l}\text { Right inferior } \\
\text { mediastinum } \\
\text { anteriorly }\end{array}$ & $\underset{\text { Pericardium }}{\text { (lightly) }}$ & None & No & 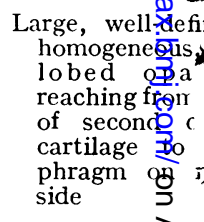 \\
\hline 8 & Present case & 1949 & $22 / 12$ & M & $\begin{array}{l}\text { Right inferior } \\
\text { mediastinum } \\
\text { anteriorly }\end{array}$ & $\begin{array}{l}\text { Pericardium, } \\
\text { sternum, an- } \\
\text { terior ends } \\
\text { of 2nd-4th } \\
\text { intercostal } \\
\text { spaces. Dia- } \\
\text { phragm }\end{array}$ & $\begin{array}{l}\text { Lobulated swelling in } \\
\text { 2nd right intercostal } \\
\text { space l in. in diameter }\end{array}$ & No & 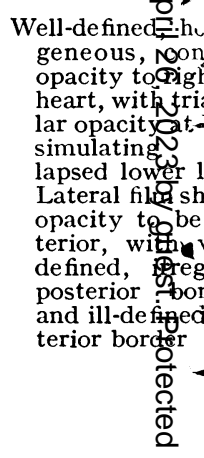 \\
\hline
\end{tabular}


and 8 (Table I). In the patient (Case 3) reported by Skinner and Hobbs (1936) the opacity occupied the lower half of the chest. The trachea and oesophagus were displaced to the left by the posteriorly placed superior mediastinal hygroma reported by Sanes, MacManus, and Scatchard (1945). This was the only instance in which displacement of mediastinal structures occurred. Such displacement appears to be more commonly produced by cervico-mediastinal hygromata than by those confined to the chest. The radiological features do not differentiate hygromata from other masses in the mediastinum.

Treatment.-The treatment of cystic hygromata in the neck is discussed at length by Goetsch (1938) and by Gross and Goeringer (1939) both of whom showed that excision gives results which are far superior to any other method. These authors reviewed the dangers and disadvantages of treatment by deep $x$ rays, radium, and chemical sclerotics. Goetsch (1938) treated 12 hygromata (11 cervical and one cervico-mediastinal) by excision with only one death, and one recurrence, which was cured by a second operation. Seven of his patients were infants. Gross and Goeringer (1939) excised 27 hygromata of the neck with only two deaths. There was no recurrence amongst the 22 patients followed up for one to 13 years. Nearly all their patients were infants and young children under the age of 2 years. Both groups of workers stress the importance of not rupturing the cysts during the dissection, because if this is done the boundaries of the mass are difficult to define, and portions may be left behind which will account for subsequent recurrence. The results obtained by these workers indicate that excision of hygromata of the neck can be performed with very low mortality and recurrence rates, even in infants, and are an encouragement to the surgeon faced with a similar condition in the mediastinum.

Gross and Hurwitt (1948) have shown that the best method of treating cervicomediastinal hygromata is by excision of the entire mass through an incision in the neck. If the whole of the mediastinal portion cannot be removed they advise destroying the remaining part by chemical sclerosis at the time of the operation, and should it recur they advocate its removal by subsequent thoracotomy.

Whatever view may be held regarding the treatment of cervical and cervicomediastinal hygromata there is little doubt that those situated wholly within the thorax should be excised. The principal reason why the authors feel this to be the correct procedure is that it is impossible to make the diagnosis without opening the chest. Furthermore this variety of hygroma is usually recognized at an age when thoracotomy can be performed with relative safety, and the removal of hygromata situated in the mediastinum is easier than is that of those located in the neck, especially when the thorax is also involved. This is because the tissue planes of the mediastinum are less complicated than are those of the neck. Reference to Table I shows that the hygroma was successfully removed in all six patients subjected to operation. None of the authors quotes a recurrence, but in only two instances is the time of post-operative observation stated. This was 20 months in the case reported by Skinner and Hobbs, and three years in that of Gross and Hurwitt. In the case reported here the time since operation was performed is too short to allow of any pronouncement. 


\section{SUMMARY}

A case of cystic hygroma of the mediastinum is reported, and seven other cases from the literature are presented.

The pathological, clinical, and radiological features of the condition are discussed, and are compared with those of cervical and cervico-mediastinal hygromata. Comparative differences between the age and sex incidence in the two groups are noted and the clinical silence of the mediastinal hygromata is emphasized.

Treatment by excision is advised, and the reasons for this opinion are given.

We wish to express our thanks to Dr. F. Lee Lander and Mr. C. Price Thomas for allowing us to publish this case, to Dr. A. B. Hill for his examination of and report upon the pathological material, and to Dr. L. G. Blair for his permission to make use of the $x$-ray films.

\section{REFERENCES}

Blades, B. (1946). Ann. Surg., 123, 749.

Bradford, M. L., Mahon, H. W., and Grow, J. B. (1947). Surg. Gynec. Obstet., 85, 467.

Bumin, H. (1939). Türk tip Cem. Mec., 5, 116.

Eigler, W. (1926). Dtsch. Z. Chir., 199, 133.

Eliaschewitsch, P. A. (1928). Virchows Arch., $270,868$.

Goetsch, E. (1938). Arch. Surg., 36, 394.

Greenfield, I., Steinberg, I., and Touroff, A. S. W. (1943). J. thorac. Surg., 12, 495.

Gross, R. E., and Goeringer, C. F. (1939). Surg. Gynec. Obstet., 69, 48.

and Hurwitt, E. S. (1948). Ibid., 87, 599.

Kinsella, T. J. (1945). "Thoracic Tumours" in Diagnosis and Management of the Thoracic Patient, Bailey, C. P., Philadelphia. Lippincott \& Company. P. 176.

Lambert, A. V. S. (1940). J. thorac. Surg., 10, 1.

Leahy, L. J., and Culver, G. J. (1947). Ibid., 16, 695.

Lenkeit, W. (1929). Zbl. allg. Path. path. Anat., 44, 97.

Michaelis, O. (1934). Dtsch. Z. Chir., 242, 250.

Sanes, S., MacManus, J. E., and Scatchard, G. N. (1945). J. thorac. Surg., 14, 253.

Seidel, I. D. (1904). Inaug. Dissert., Leipzig. Cited from Ewing, J. (1940). Neoplastic Diseases, p. 1001. Philadelphia and London. W. B. Saunders Co., 1940.

Skinner, G. F., and Hobbs, M. E. (1936). J. thorac. Surg., 6, 98.

Thompson, J. V. (1947). Int. Abstr. Surg., 84, 195.

Watson, W. L., and Diamond, H. D. (1947). J. thorac. Surg., $16,1$. 